\title{
Kritik Sosial dalam Dua Puisi Dikumpulan Puisi "Malu (Aku) Jadi Orang Indonesia (Majoi)" Karya Taufiq Ismail
}

\author{
Esa Klara Sukmawati \\ Universitas Indraprasta PGRI \\ Jalan Nangka No. 58 C/TB. Simatupang, Tanjung Barat, Jakarta Selatan 12530 \\ esa.klara@yahoo.co.id
}

\begin{abstract}
The research aims to find out various social problems, as well as anyone who is criticized, the contents of criticism and how to deliver in two poems in the "Majoi" poetry collection by Taufiq Ismail. The research was conducted with qualitative research methods, analyzing, and describing social criticism contained in two poems in the "Majoi" poetry collection with a semiotic approach. This study uses content analysis techniques the results of the study obtained conclusions as follows: 1) The problem that occurred in "Majoi" and Poetry poems May 12, 1998 is. Interrelated problems in both poems where "Majoi"'s poetry is a matter of bureaucratic infidelity, cheating in business, court decisions that can be bargained so that the law can be bought, political problems in which elections can be played out openly and lower and middle class people can be suppressed by government. Whereas, in the poem May 12, 1998 explained the disagreement of the New Order government system so that KAMI (Kesatuan Aksi Mahasiswa Indonesia) and the four martyrs held an action for the total Revolution. Until the action was given the name Trisakti Tragedy. 2) The targets aimed at "Majoi" poetry were government, businessmen, and the community. Whereas poetry on May 12, 1998 was aimed at educational institutions. 3) The way to convey criticism in both poems is to be conveyed in a clear, straightforward manner with full satirical language arranged systematically without any events being missed. Until the action was given the name Trisakti Tragedy. 2) The targets aimed at "Majoi" poetry were government, businessmen, and the community. Whereas poetry on May 12, 1998 was aimed at educational institutions. 3) The way to convey criticism in both poems is to be conveyed in a clear, straightforward manner with full satirical language arranged systematically without any events being missed.
\end{abstract}

Keywords: criticism, social, poetry.

\begin{abstract}
Abstrak
Penelitian bertujuan untuk mengetahui berbagai masalah sosial, serta siapa saja yang dikritik, isi kritik dan cara penyampaian dalam dua puisi di kumpulan puisi "Majoi" karya Taufiq Ismail. Penelitian dilakukan dengan metode penelitian kualitatif, menganalisis, dan mendeskripsikan kritik sosial yang terdapat dalam dua puisi dengan pendekatan semiotika. Penelitian ini menggunakan teknik analisis isi. Hasil penelitian memperoleh simpulan sebagai berikut: 1) Masalah yang terjadi pada puisi "Majoi” dan Puisi "12 Mei 1998” adalah saling berkaitan di kedua puisi tersebut di mana pada puisi "Majoi" adalah masalah perselingkuhan birokrasi, kecurangan dalam berbisnis, keputusan pengadilan yang dapat tawar-menawar sehingga hukum bisa dibeli, masalah politik di mana pemilu dapat dipermainkan terang-terangan dan masyarakat kelas bawah dan menengah dapat ditindas oleh pemerintah. Dalam puisi "12 Mei 1998" menjelaskan ketidaksetujuan sistem pemerintahan Orde Baru sehingga KAMI (Kesatuan Aksi Mahasiswa Indonesia) dan empat syuhada tersebut menggelar aksi untuk revolusi total. Hingga aksi tersebut diberi nama Tragedi Trisakti. 2) Sasaran yang ditujukan pada puisi "Majoi" adalah pemerintah, pengusaha, dan masyarakat. Puisi "12 Mei 1998" ditujukan untuk lembaga pendidikan. 3) Cara menyampaikan kritikan pada kedua
\end{abstract}


puisi tersebut yaitu di sampaikan secara jelas, lugas dengan penuh bahasa sindiran yang disusun secara sistematis tanpa ada satu peristiwa yang terlewati.

Kata Kunci: kritik, sosial, puisi

\section{PENDAHULUAN}

Pada zaman Orde Baru puisi merupakan saran untuk mengkritik dan mengekspresikan diri melalui media tulis. Hal itu sejalan dengan pendapat Wellek dan Werren dalam Pradopo (2017: 74) yang mengemukakan bahwa "karya sastra adalah imajinasi (rekaan) bermedium bahasa yang fungsinya estetikanya dominan.". oleh karena itu, puisi merupakan salah satu karya sastra yang menggambarkan kehidupan dengan mengangkat masalah-masalah yang terjadi di masyarakat.

Membaca puisi-puisi yang bertemakan kritik membuka ingatan kita terhadap masa Orde Baru. Pada masa Orde Baru, menurut Herman (Waluyo,1987: 263), “Angkatan 66 berbicara tentang tegaknya kembali pancasila dan UUD 45, tegaknya kebenaran dan keadilan di bumi Indonesia. Humanisme universal dan human dignity tidak dipersoalkan lagi, tetapi penyelewengan dari rel Pancasila, rel UUD 45, rel kebenaran, dan keadilan yang dibicarakan secara keras".

Oleh sebab itu, pada era pemerintahan Orde Baru, Taufiq Ismail menuliskan perasaannya di kumpulan puisi yang berjudul "Majoi", akronim dari "Malu (Aku) Jadi Orang Indonesia". Kumpulan puisi "Majoi" merupakan puisi yang berisi protes ungkapan hati terhadap pemerintah yang disiratkan melalui larik-larik sajak.

Sebagai penyair Taufiq Ismail menggambarkan keadaan kelas sosial dari kalangan kelas bawah, menengah dan atas dengan tepat sesuai proses terjadinya. Taufiq Ismail mempunyai kekhasan tersendiri yang menjadi ciri puisi tersebut yaitu: menuliskan kejadian demi kejadian secara jelas, serta mengungkapkan segala duka laranya dalam puisi dengan bahasa sederhana dan mudah untuk dipahami oleh khalayak umum dan mengungkapkan sindirannya secara sopan santun.

Berbagai persoalan dalam masalah sosial di masyarakat pada zaman Orde Baru yang terjadi dalam masyarakat Indonesia. Kalangan kelas menengah dan kelas bawah pada masyarakat Indonesia pada dasarnya seringkali menjadi titik perhatian KAMI (Kesatuan Aksi Mahasiswa Indonesia) di kalangan pemuda supaya Indonesia dapat terbebas dari deformasi. Oleh sebab itu, kedua puisi tersebut memiliki keterkaitan mengenai permasalahan pada zaman Orde Baru. penulis tertarik untuk mengkaji sasaran kritik yang terdapat di dalam kumpulan puisi "Majoi". Berdasarkan uraian di atas, peneliti ingin menyoroti kritik sosial terhadap pemerintahan yang ada dalam masyarakat yang terdapat di dalam dua puisi di kumpulan puisi "Majoi” karya Taufiq Ismail.

\section{Hakikat puisi}

Puisi merupakan salah satu genre sastra yang memiliki nilai estetika tertinggi. Menurut Shelly (dalam Gumiati dan Mariah, 2010 : 5) "puisi adalah rekaman detikdetik yang paling indah dalam hidup kita, misalnya peristiwa-peristiwa yang sangat mengesankan dan menimbulkan keharuan yang kuat, seperti kebahagiaan, kegembiraan yang memuncak, percintaan, bahkan kesedihan karena kematian 
orang yang sangat dicintai, puncak pengalaman itu merupakan momen yang baik untuk direkam dalam bentuk puisi" sehingga puisi bukan sarana sebagai alat komunikasi yang sederhana melainkan sebagai pengalaman yang unik dan vitamin batin, kerja otak kanan yang membuat halus sikap hidup insani, yang menjadikan politik dan sikap berpolitik lebih santun dan beradab. Menurut Waluyo (1987: 25), "puisi adalah bentuk karya sastra yang mengungkapkan pikiran dan perasaan penyair secara imajinatif dan disusun dengan mengonsentrasikan semua kekuatan bahasa dengan pengonsentrasian struktur fisik dan struktur batin". Oleh karena itu, puisi bukanlah metode komunikasi yang sederhana tetapi merupakan pengalaman yang unik dan puisi itu vitamin batin, kerja otak kanan yang membuat halus sikap hidup manusia, yang menjadikan politik dan sikap berpolitik lebih santun dan beradab.

\section{Hakikat Kritik Sosial}

Kritik sastra muncul karena masalah sosial yang terjadi di masyarakat. Masalah sosial tersebut karena ketidak sesuaian manusia atau kelompok sosial. Selain dari faktor masalah sosial kritik sastra lahir dari pembaca yang menganggap adanya ketidak sesuaian terhadap norma yang berlaku. Menurut Andre Hardjana dalam Zulfahnur (2016: 116) "mendefinisikan kritik sastra sebagai hasil usaha pembaca dalam mencari dan menentukan nilai hakiki karya sastra lewat pemahaman dan penafsiran secara sistemik yang dinyatakan dalam bentuk tulisan." Oleh karena itu, kritik sosial hadir karena ketidak sesuaian norma-norma yang berlaku di masyarakat.

Dengan demikian, karya sastra dapat dijadikan sebagai sarana media untuk menyampaikan suatu gagasan mengenai permasalahan dan keadaan masyarakat. Sebagaimana diungkapkan oleh Faruk (2017: 46) bahwa "sebagai bahasa karya sastra sebenarnya dapat dibawa ke dalam keterkaitan yang kuat dengan dunia sosial tertentu yang nyata, yaitu lingkungan sosial tempat karya sastra itu hidup dan berlaku".

Dari pendapat di atas dapat ditarik kesimpulan bahwa munculnya kritik sosial karena permasalahan yang ada di masyarakat sehingga kritik sosial merupakan ungkapan hati masyarakat mengenai apa yang dilihat masyarakat, apa yang dirasakan masyarakat dan apa yang didengar masyarakat yang dituangkan dalam bentuk sindiran, ejekan, bahkan celaan dengan maksud menyadarkan objek sasaran.

\section{Keterkaitan Kritik Sosial dengan Karya Sastra}

Karya sastra merupakan komunikasi penulis yang bertujuan untuk memberikan nilai yang bertujuan untuk memberikan nilai estetika pada suatu karya yang di lihat dari dunia sosial. Di dunia sosial sesuatu yang dianggap menyimpang akan menjadi bahan kritik untuk menegakkan keadilan.

Dengan demikian, kritik sosial dapat mengupayakan suatu perubahan terhadap permasalahan yang ada di masyarakat. Menurut H.B Jassin dalam Endasawara (2013: 3) "bahwa kritik kesusastraan adalah pertimbangan baik atau buruk sesuatu hasil kesusastraan, dengan alasan-alasan mengenai isi dan bentuk hasil kesusastraan". Berdasarkan uraian di atas, kritik sastra yang dilakukan penyair dalam karya sastra menjadi sah dan tidak sah yang tidak dipermasalahkan 
keberadaannya. Selain itu, kritik sosial yang diungkapkan melalui karya sastra (puisi) bisa mencakup segala macam kehidupan sosial di negeri ini, sebagai contoh hubungan manusia dengan manusia, manusia dengan lingkungannya, manusia lain, kelompok sosial, penguasa dan institusi.

\section{Masalah Sosial Sebagai Sumber Munculnya Kritik Sosial}

Ketidaksesuaian antara unsur-unsur kebudayaan dan masyarakat disebut masalah sosial merupakan sehingga dapat membahayakan kelompok sosial, serta dapat menghambat terpenuhinya keinginan-keinginan pokok masyarakat.

Hubungan antara aspek-aspek tersebut selalu ada karena aspek-aspek dalam masyarakat, di dalam keadaan yang wajar, merupakan suatu integrasi yang mempunyai hubungan yang saling mempengaruhi. Menurut Soekanto (2015: 319) ada beberapa persoalan yang dihadapi oleh masyarakat yang pada umumnya sama, yaitu: Masalah Kemiskinan, birokrasi,

\section{Cara Menyampaikan Kritik Sosial}

Tema dan sasaran disesuaikan untuk cara menyampaikan kritik sosial pengarang dengan berbagai macam cara. Pengungkapan tersebut disesuaikan dengan tema dan sasarannya. Menurut Nurgiyantoro (2013: 460) "membagi bentuk penyampaian pesan (kritik) menjadi dua, pesan moral langsung dan tidak langsung". Bentuk penyampaian secara langsung dilukiskan yang bersifat uraian. Hal tersebut, memudahkan pembaca dalam memahami pesan yang terkandung. Bentuk penyampaian secara tidak langsung bersifat tersirat di dalam cerita, berpadu secara koherensif dengan unsur-unsur cerita lainnya.

Menurut Sarwadi (dalam Abdullah, 2014: 13-14) menyatakan bahwa sastrawan dapat menyampaikan kritiknya terhadap kehidupan sosial menggunakan berbagai macam cara. Cara tersebut meliputi lima hal berikut ini yaitu: Kritik yang Bersifat Lugas, simbolik, humor, interpretatif dan sinis.

\section{Hakikat Semiotika}

Menurut (Kurniawan, 2013:123) "kata semiotika (ada yang menyebut semiologi) berasal dari bahasa yunani, "semeion" yang berarti tanda. Dengan demikian, semiotika berasal dari kata semeion, yang berarti tanda.

Menurut Nurgiantoro (2013: 67) "semiotika adalah tanda, tanda adalah sesuatu yang mewakili sesuatu yang lain yang dapat berupa pengalaman, pikiran, perasaan dan lain-lain.". Dari kedua pendapat di atas dapat disimpulkan bahwa semiotika adalah ilmu yang sistematis dan mempelajari tanda-tanda yang bermanfaat terhadap kehidupan. Sedangkan menurut Roland Barthes dalam buku (Zaimar,2008: 33) "ada tiga tataran dalam penelitian semiotika yaitu: a) tataran peristiwa, disebut juga hubungan unsur teks secara sintagmatik, b) tataran tindakan, disebut juga hubungan unsur teks secara paradigmatic, c) tataran pengujaran".

Dengan demikian, semiotika adalah ilmu yang sistematis yang mempelajari tanda-tanda, bukan hanya tanda-tanda dalam bahasa tetapi tanda-tanda dalam kehidupan. 


\section{Semiotika dalam Karya Sastra}

Karya sastra merupakan karya yang mempunyai tanda-tanda yang tandatanda tersebut memiliki makna sesuai dengan porsinya masing-masing. Menurut Pradopo (2013: 108-109) "karya sastra merupakan sistem semiotik tingkat kedua yang mempergunakan bahasa sebagai sistem semiotik tingkat pertama". Dengan demikian, perasaan, pikiran, dan keinginan pengarang dapat diungkapkan melalui karya sastra dengan bahasa yang khas, yaitu bahasa yang memuat semiotika yang terdapat tanda-tanda. Menurut (Endraswara, 2013:37) "semiotika adalah ilmu yang mempelajari tentang tanda, dan produksi makna".

Dengan demikian, semiotika dalam sastra bukanlah suatu aliran, melainkan bahasa alam yang dipakai dalam sastra yang di kaitkan dengan tanda-tanda sehingga dapat membaca tanda-tanda tersebut.

\section{METODE}

Metode penelitian merupakan pijakan peneliti untuk meneliti suatu objek secara sistematis. Hal itu dijelaskan Meleong (2004:17) "yang mengatakan bahwa metode penelitian yang dilakukan secara sistematis dan terstruktur sesuai dengan objek penelitian serta jenis penelitian". Menurut Ratna (2013: 47) "Metode kualitatif memberikan perhatian terhadap data alamiah, data dalam hubungannya dengan konteks keberadaannya". Oleh karena itu, metode yang digunakan dalam penelitian ini adalah metode deskriptif kualitatif.

Penelitian ini difokuskan pada kritik sosial pada antologi puisi Malu (Aku) Jadi Orang Indonesia karya Taufiq Ismail. Subfokus pada penelitian ini terdiri dari isi kritik, cara menyampaikan kritik, dan sasaran yang dikritik dalam antologi puisi Malu (Aku) Jadi Orang Indonesia karya Taufiq Ismail.

Adapun langkah-langkah yang dilakukan dalam analisis data adalah sebagai berikut: 1) Mengumpulkan data yang berupa kumpulan puisi "Majoi” Karya Taufiq Ismial. 2) Membaca berulang-ulang untuk memahami teks sehingga yang akan dianalisis berhubungan dengan apa yang akan diteliti. 3) Membaca dan mempelajari literatur, referensi atau bahan pustaka yang mempunyai hubungan dan menunjang terhadap persoalan dan permasalahan dalam penelitian ini, mencatat hal-hal penting yang diharapkan dapat menemukan kajian-kajian yang relevan serta berkesinambungan dengan puisi yang dipilih yang sesuai dengan kritik sosial puisi sehingga mampu melahirkan suatu jawaban yang memunculkan jawaban dari kritik sosial dari kumpulan puisi yang dikaji. 4) Mencatat dan memasukkan data yang diperoleh ke dalam instrument analisis data. 5) Memberi interpretasi dan simpulan dari hasil analisis data sesuai dengan fokus penelitian dan tujuan penelitian.

\section{HASIL DAN PEMBAHASAN}

\section{Hasil}

Deskripsi data ini menyajikan berbagai informasi yang terdapat dalam dua puisi dikumpulan puisi "Majoi” karya Taufik Ismail yang memiliki keterkaitan dengan 
kritik sosial mengenai isi puisi, cara menyampaikan kritik, dan sasaran kritik.

Dua puisi karya Taufik Ismail yang dikemas dengan sejarah pada masa Orde Baru yang mengkritisi lembaga pemerintahan, lembaga pendidikan, lembaga birokrasi, politik dan masyarakat. Dua puisi tersebut yaitu puisi "Majoi" dan "12 Mei 1998" saling keterkaitan yaitu sama-sama membicarakan kehidupan, khususnya kekuasaan pemerintahan. Taufik Ismail seakan-akan menggambarkan kehidupan yang dimulai dari deformasi ke reformasi. Selain itu, fase pendukung tidak luput dari pembahasan.

Berikut penjelasan dari SIP pada puisi "Majoi". Terdapat 41 sekuen yang berada pada alur penceritaan puisi. Bagian 1, bait ke-1 sampai bait ke-5 disebut puisi naratif karena memperkenalkan siapa aku dan siapa sahabat aku (Thomas). "Aku adalah siswa SMA di Purwokerto yang mendapat beasiswa ke Wicousin. Thomas yang bangga terhadap Indonesia". Pada bagian 2 bait ke-5 disebut puisi liris yang mengalami repetisi dengan bagian 4 bait ke-7. Bagian 2 dan bagian 4 disebut repetisi liris karena berisi ungkapan hati Aku yang malu terhadap bangsanya. Selain itu, jawaban puisi liris pada bagian ke-2 dan ke-4 dijawab secara sistematis dengan bentuk puisi naratif pada bagian ke-3 nomor 18 sampai nomor 37.

Dari sekuen-sekuen yang telah dijabarkan dalam puisi secara detail, dapat dilihat peristiwa-peristiwa yang terjadi dalam bentuk satu kesatuan yang dapat ditarik benang merahnya, yaitu pengujar atau "aku" merasa sangat malu terhadap bangsanya yang sangat-sangat bobrok. Aku adalah tokoh yang sudah remaja dan dapat menilai kebusukan bangsanya yang dijelaskan SIP pada nomor 1-2. Aku sangat kecewa terhadap bangsaku di mana, zaman SMA Aku bangga terhadap Indonesia yang dapat terbebas dari belenggu Belanda seperti yang di jelaskan SIP pada nomor 1- 4. Sehingga, Aku yang selalu menceritakan kehebatan Indonesia merebut kemerdekaannya kepada Sahabatnya (Thomas) yang dijelaskan SIP pada nomor 5-6. Di mana pada saat itu Aku menjadi narasumber di peristiwa Surabaya dan tokoh utamanya Bung Tomo di saat itu aku bangga karena negeriku baru merdeka enam tahun, tetapi sudah dikenal negara seperti yang dijelaskan SIP pada nomor 4-6, tetapi ketika aku mengetahui kebusukan Negeriku, hilang semua rasa bangga itu. Rasa bangga itu semua berubah menjadi rasa malu yang bertaraf Internasional. Sehingga, aku makin merasa malu bertemu dengan sahabatku seperti yang dijelaskan SIP pada nomor 11-14.

Berikut Penjelasan dari SIP pada Puisi 12 Mei 1998. Dalam puisi 12 Mei 1998 terdapat 16 sekuen yang berada pada saat alur penceritaan puisi. Pada puisi 12 Mei 1998 bait ke-1 sampai bait ke-6 disebut puisi naratif karena memperkenalkan siapa empat mahasiswa yang gugur dalam Tragedi Trisakti serta diceritakan secara sistematis.

Dari sekuen-sekuen yang telah dijabarkan dalam puisi secara detail, dapat dilihat peristiwa-peristiwa yang terjadi dalam bentuk satu kesatuan yang dapat ditarik benang merahnya, yaitu untuk mengenang empat mahasiswi yang gugur pada tragedi Trisakti. Pada saat itu, semangat yang luar biasa para mahasiswa untuk menegakkan reformasi seperti yang dijelaskan pada SIP nomor 1 dan 3. Sehingga, empat mahasiswa itu menyembunyikan identitasnya dan menyimpan semua citacitanya untuk Indonesia yang lebih baik lagi seperti yang di jelaskan pada SIP 
nomor 6. Untuk Indonesia impian mereka pada abad ke-21 untuk menjadi sarjana mereka gugurkan seperti yang dijelaskan SIP pada nomor 8. Dengan demikian, dari hasil runtutan SIP dan pembahasan SIP pada puisi 12 Mei 1998 dapat disimpulkan bahwa puisi "12 Mei 1998" adalah terdiri dari puisi naratif. Puisi ini mengungkapkan rasa sedihnya terhadap empat syuhada yang gugur dalam menegakkan reformasi dan kami berdoa bersama untuk mengenang kepergian empat syuhada tersebut serta meminta petunjuk Tuhan untuk menyelesaikan tragedi Trisakti.

\section{Analisis Tokoh dan Analisis Setting (Ruang dan Waktu) \\ Tokoh Puisi "Majoi"}

Dari pembahasan tokoh di atas dapat disimpulkan bahwa tokoh "aku" merupakan tokoh yang berani mengungkapkan apa yang dia lihat, dia rasa, dan dia dengar mengenai Indonesia. Tokoh "Jas Safari" adalah tokoh pemerintah yang memakan uang rakyat dari rakyat kelas bawah sampai rakyat kelas atas. Selain itu, ada tokoh "Pengusaha" yang bermain curang dalam dunia bisnis sehingga apa yang dia inginkan dilancarkan oleh pemerintah dalam dunia birokrasi. Tokoh yang terakhir adalah tokoh "masyarakat", tokoh tersebut dibagi tiga yaitu masyarakat kelas bawah, menengah, dan atas sehingga sangat terlihat jelas siapa yang diuntungkan dan siapa yang dirugikan, membuat kebobrokan negerinya, sedangkan, tokoh "masyarakat" adalah tokoh yang tertindas oleh pemerintah.

\section{Puisi "12 Mei 1998"}

Dari pembahasan di atas dapat disimpulkan puisi ini adalah puisi persembahan untuk empat syuhada yang tertera dalam SIP nomer 8. Pada puisi ini terdapat tokoh Akronim KAMI yaitu "Kesatuan Aksi Mahasiswa Indonesia" para pemuda yang ingin menceritakan tragedi Trisakti. Para pemuda itu mempunyai semangat untuk kemajuan Indonesia, seperti yang dijelaskan SIP pada nomor 16.

\section{Ruang dan Waktu Puisi "Majoi"}

Dari pembahasan ruang dan waktu di atas dapat disimpulkan bahwa ruang waktu dalam pembuatan puisi secara runtut dimulai tahun 1959 saat penutur masih duduk di bangku SMA hingga 1998 ketika penutur sudah menjadi penulis yang sering berjalan-jalan di luar kota.

\section{Ruang dan Waktu Puisi 12 Mei 1998}

Dari pembahasan ruang dan waktu di atas dapat disimpulkan bahwa ruang waktu dalam pembuatan puisi secara runtut dimulai tahun 1998 saat Orde Baru yang saat itu sedang bergejolaknya reformasi total. Warga Indonesia menginginkan negara yang demokrasi, negara yang tidak bisa membeli hukum. Oleh karena itu, penutur memberikan persembahan puisi 12 Mei 1998 untuk keempat syuhada yang gugur dalam Tragedi Trisakti di mana empat syuhada itu menyembunyikan identitasnya dan menyimpan semua cita-citanya untuk Indonesia.

\section{Pembahasan}




\section{Kritik Sosial dalam Puisi "Majoi" \\ Kritik masalah birokrasi}

Perselingkuhan birokrasi di Indonesia mendapatkan urutan pertama seperti yang dijelaskan SIP pada nomor 18. Perselingkuhan itu bisa terjadi karena kecurangan bisnis seperti yang dijelaskan SIP pada nomor 19. Pebisnis mengadakan kecurangan terhadap pemerintah supaya masalah dunia bisnis cepat teratasi. Ironisnya segala cara bisa dijalankan pemerintah untuk kenyamanan pebisnisnya seperti yang dijelaskan SIP pada nomor 27. Dalam puisi menyatakan bahwa Indonesia merupakan Negara yang kaya akan suap-menyuap pada masa Orde Baru tahun 1998 sehingga kata krismon pada tahun 1998 bukan kata yang asing karena pada saat itu harga sembako melambung tinggi hingga rakyat kelas mengah dan kelas bawah menangis. Kenaikan bahan pokok menjadikan petinggi semakin kaya, dan rakyat kecil semakin miskin, seperti yang sudah dijelaskan SIP pada nomor 23. Oleh karena itu, dalam kutipan puisi tersebut menjelaskan separuh dari harga jual dipotong birokrasi mulai dari alat-alat yang mahal hingga sebuah peuyeum yang menjadi ciri khas makanan orang sunda masih dipotong birokrasi yang masuk ke kantong pemerintah seperti yang dijelaskan SIP pada nomor 22.

\section{Kritik masalah politik}

Pada bagian ini penutur menyadari, sengsaranya penduduk Indonesia pada waktu itu seperti yang di jelaskan SIP pada nomor 25. Puisi tersebut penuh penekanan, kata "sangat" diulang-ulang sampai empat kali, pengulangan tersebut benar-benar menjelaskan pada saat itu pemilihan umum tidak jujur. Dalam kurun waktu 32 tahun, setelah Supersemar 66' sampai Reformasi 98' Golkar berturut-turut menang mutlak. Soeharto diangkat menjadi presiden seumur hidup. Pada saat itu PNS, ibuibu PKK mendukung Golkar habis-habisan.

\section{Kritik masalah hukum}

Di Indonesia pada masa Orde Baru menunjukkan adanya kegelisahan di masyarakat. Secara logika, sebuah negara hukum seharusnya memiliki pilar hukum yang kuat, tetapi hal ini tampaknya tidak ditemui karena keputusan pengadilan bisa dinegosiasikan dan hukum dapat dibeli seperti yang dijelaskan SIP pada nomor 30. Gambaran SIP pada nomor 30 menjelaskan kasus-kasus kelemahan hukum di Indonesia. Jika dahulu orang masih berpikir beberapa kali untuk melakukan kecurangan atau perbuatan yang melanggar hukum, maka kini karena didorong oleh ambisi pribadinya yang lebih besar, orang dengan tenang atau tanpa rasa bersalah sering melakukan perbuatan-perbuatan yang melanggar hukum. Begitu banyak perbuatan melanggar hukum yang sudah tidak malu-malu lagi dilakukan orang. Oleh sebab itu, penyair merasa kesulitan menemukan perbuatan-perbuatan yang mulia. Ia pun dengan gundah mengungkapkan seperti yang dijelaskan SIP pada nomor 44.

\section{Kritik Sosial dalam Puisi "12 Mei 1998"}

Pada puisi "12 Mei 1998" mengungkapkan Ketidakpuasan dalam lingkup pemerintahan yang totaliter. Masalah sosial yang terdapat dalam kumpulan puisi tersebut hanyalah masalah sosial yang sangat erat kaitannya dengan kritik sosial,

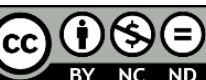


yaitu:

\section{Kritik terhadap pemerintahan}

Pemberian judul pada puisi Taufiq tersebut sangat jelas mengacu pada peristiwa 12 Mei 1998 yang dikenal dengan sebutan Tragedi Trisakti atau Insiden Trisakti. Insiden ini diawali dengan peristiwa demonstrasi para mahasiswa menuntut perubahan akan pemerintahan yang demokratis dan reformasi total seperti yang dijelaskan pada nomor 3. Insiden terjadi di kampus Universitas Trisakti di Jalan Kyai Tapa, Grogol, Jakarta. Insiden ini merupakan peristiwa kelabu saat-saat awal menjelang detik-detik akhir kekuasaan Soeharto (Orde Baru) seperti yang dijelaskan SIP pada nomor 11 dan 12. Dengan demikian KAMI berdoa dan memohon petunjuk kepada Tuhan untuk dapat menyelesaikan Tragedi Trisakti seperti yang dijelaskan SIP pada nomor 15 sampai 16.

\section{Kritik terhadap lembaga pendidikan khususnya Universitas.}

Perjuangan mahasiswa yang gugur dalam Insiden Trisakti merupakan perjuangan yang layak dihargai dan selalu diingat seperti yang dijelaskan SIP pada nomor 9, sehingga, nilai perjuangan itu, memiliki kadar yang dapat melebihi nilai-nilai yang diperoleh secara akademik di ruang kuliah. Indeks prestasi (IP) yang selama ini hanya diperoleh para mahasiswa melalui bangku kuliah, tidak begitu berarti dibandingkan dengan perjuangan empat mahasiswa yang gugur dalam Insiden Trisakti.

Pada saat ini banyak mahasiswa yang tidak peduli pada situasi dan kondisi bangsanya, karena terlalu sibuk dengan orientasi kerja setelah memperoleh IP tinggi dari bangku kuliah. Tentu saja keikhlasan empat pahlawan reformasi yang telah mengorbankan nyawa, yang telah merelakan harapan dan cita-cita orang tuanya terhempas begitu saja, layak untuk diberi penghargaan yang lebih dibandingkan dengan para mahasiswa yang hanya sibuk mengejar IP di ruang kuliah. IP empat mahasiswa yang gugur dalam Insiden Trisakti, tidak hanya tertinggi di Trisakti, tetapi tertinggi dari seluruh perguruan tinggi yang ada di negeri ini. Larik-larik berikut mengindikasikan bahwa penyair mempunyai penghargaan terhadap perjuangan yang telah dilakukan para mahasiswa Trisakti dalam mewujudkan citacita reformasi.

\section{Sasaran yang di Kritik}

Sasaran yang dikritik dalam puisi ini dapat ditarik kesimpulan dari hasil analisis tokoh yang akan di jelaskan sebagai berikut.

\section{Puisi "Majoi"}

Bentuk kritik sosial masyarakat juga terjadi dalam puisi Taufiq Ismail yang berjudul "Malu (Aku) jadi orang Indonesia", "kejahatan bukan kelas maling sawit melainkan permainan lahan duit dalam" kutipan tersebut jelas bahwa dalam era yang sudah terjadi yaitu masyarakat menganggap bahwa kejahatan sudah tidak dianggap tabu lagi melainkan sebagai pekerjaan bagi orang tertentu yang melakukannya. Kritik yang terjadi di kehidupan masyarakat ini menunjukkan sebuah kejahatan tidak ditakuti lagi, melainkan sebagai wadah untuk menghidupi keluarganya. Seakanakan masyarakat yang tinggal di bawah naungan tersebut tertekan dengan keadaan 
yang dialami Indonesia. Dengan demikian, sasaran kritik yang terdapat dalam kumpulan puisi "Malu (Aku) Jadi Orang Indonesia" ("Majoi") Karya Taufiq Ismail hanyalah sasaran yang erat kaitannya dengan kritik sosial, yaitu:

a) sasaran kritik birokrasi.

b) sasaran kritik politik.

c) Sasaran Kritik hukum

\section{Puisi “12 Mei 1998”}

Kata persembahan penutur yang ditulis sesudah judul puisi "12 Mei 1998”, yakni mengenang Elang Mulya, Hery Hertanto, Hendriawan Lesmana dan Hafidhin Royan adalah catatan yang dibuat penutur sesuai dengan isi puisi yang ditulisnya. Dari catatan tersebut dapat diketahui bahwa penulisan puisi "12 Mei 1998" penutur buat dari sejarah apa yang penutur lihat, penutur rasakan sehingga kaitannya dengan peristiwa penting yakni Insiden Trisakti 12 Mei 1998. Puisi ini ditulis penutur untuk mengenangkan jasa empat pahlawan reformasi, yang rela mengorbankan citacitanya untuk kemajuan bangsanya yang terbebas dari deformasi. Dengan demikian, puisi menyoroti pemerintahan karena masyarakat merasa tertekan akan kebijakan pemerintah yang tidak demokrasi dan mahasiswa yang mementingkan IP dari pada kemajuan bangsa.

\section{Cara Menyampaikan Isi Kritik}

Cara menyampaikan isi kritik yang disampaikan dalam dua puisi ini dapat dilihat dari alur penelitian atau dari sekuen yang akan dijelaskan sebagai berikut:

\section{Puisi "Majoi"}

Isi kritik puisi ini, walaupun Indonesia sudah merdeka dari tangan penjajah, Indonesia masih dijajah kaum sendiri. Banyak masalah politik, ekonomi, sosial, serta budaya yang masih harus dibenahi. Sehingga, penyampaian kritik puisi ini sebagian, menggunakan bahasa kiasan atau lambang-lambang mewakili makna sebenarnya. Seperti larik ke tujuh bab kedua "Dan kubenamkan topi baret di kepala". Kritik pada puisi simbolik ini mempunyai sifat yang lebih terbuka dalam mengungkapkan apa saja yang terjadi di Indonesia pada zaman Orde Baru secara jelas dan sistematis.

\section{Puisi "12 Mei 1998"}

Motor penggerak dari seluruh puisi di kumpulan puisi "Majoi" adalah puisi " $12 \mathrm{Mei}$ 1998". Puisi ini diciptakan dari sesuatu yang pernah dilihat, sesuatu yang dirasakan, sehingga membuat hati nurani penyair tersentuh untuk mengungkapkan semua isi hatinya mengenai bangsanya sendiri. Dengan demikian, cara menyampaikan puisi ini dengan kritik yang bersifat interpretatif, yaitu kritik yang menyampaikan kritiknya dengan cara halus. Pemaknaan kritik dengan cara interpretatif membutuhkan pengalaman, wawasan, dan pengetahuan pembaca.

\section{SIMPULAN}

Sesuai dengan rumusan masalah yang telah dijabarkan pada bab satu dan

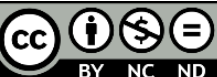


berdasarkan hasil analisis serta pembahasan mengenai kritik sosial dengan pendekatan semiotika pada kedua puisi dikumpulan puisi "Majoi" karya Taufiq Ismail dapat disimpulkan sebagai berikut:

1. Masalah yang terjadi pada puisi "Majoi" dan Puisi "12 Mei 1998" adalah saling berkaitan di kedua puisi tersebut dimana pada puisi "Majoi" adalah masalah perselingkuhan birokrasi, kecurangan dalam berbisnis, keputusan pengadilan yang dapat di tawar menawar sehingga hukum bisa dibeli, masalah politik dimana pemilu dapat dipermainkan terang-terangan dan masyarakat kelas bawah dan menengah dapat ditindas oleh pemerintah, sedangkan dalam puisi "12 Mei 1998" menjelaskan ketidaksetujuan sistem pemerintahan Orde Baru sehingga KAMI (Kesatuan Aksi Mahasiswa Indonesia) dan empat syuhada tersebut menggelar aksi untuk Revolusi total. Hingga aksi tersebut diberi nama Tragedi Trisakti.

2. Sasaran yang di tujukan pada puisi "Majoi" adalah pemerintah, pengusaha, dan masyarakat, sedangkan puisi "12 Mei 1998" ditujukan untuk lembaga pendidikan.

3. Cara menyampaikan kritikan pada kedua puisi tersebut yaitu disampaikan secara jelas, lugas dengan penuh bahasa sindiran yang disusun secara sistematis tanpa ada satu peristiwa yang terlewati.

\section{DAFTAR PUSTAKA}

Abdullah, A. A. (2014). Kritik sosiologi dalam kumpulan cerpen seekor bebek mati dikali karya: Puthut E.A. Yogyakarta: Universitas Negeri Yogyakarta

Endraswara, S. (2013). Teori kritik sastra. Jakarta: PT Buku Seru.

Faruk. (2015). Pengantar sosiologi sastra. Yogyakarta: Pustaka Belajar.

Gumiati, T., \& R. Mariah, Y. (2010). Kiat praktis menulis puisi. Bandung: Batik Press.

Kurniawan, H. (2009). Sastra anak dalam kajian strukturalisme, sosiologi, semiotika, hingga penulis kreatif. Yogyakarta: Graha Ilmu

Nurgiantoro, B. (2013). Teori pengkajian fiksi. Yogyakarta: Gajah Mada University Perss

Ratna, N. K. (2013). Teori, metode, dan teknik penelitian sastra. Yogyakarta: Pustaka Pelajar.

Pradopo, R. J. (2013). Beberapa teori, sastra, metode, kritik dan penerapannya. Yogyakarta: Pustaka Pelajar.

Pradopo, R. J. (2017). Kritik sastra Indonesia modern. Yogyakarta: Gana Media.

Soekanto, S. (2015). Sosiologi suatu pengantar. Jakarta: Rajawali Pers.

Ismail, T. (2000). Malu (Aku) Jadi Orang Indonesia. Jakarta: Yayasan Indonesia.

Waluyo, H. J. (1987). Teori dan apresiasi puisi. Jakarta: Erlangga.

Zaimar, O. K. S. (2008). Semiotik dan Penerapannya dalam Karya Sastra. Jakarta: Pusat Bahasa.

Zulfahnur. Z.F. (2016). Teori Sastra. Tangerang Selatan. Universitas Terbuka. 